\title{
HERITAGE - CONTEMPORARY USES OF CULTURE BEYOND THE EVERYDAY? \\ CHALLENGING ETHNOGRAPHY AND CULTURAL ANALYSIS
}

\section{BERNHARD TSCHOFEN}

Based on the premise that, today, "doing culture" has to be understood as both "acting in culture" and "acting with culture", this paper discusses new perspectives on the complex field of cultural heritage. Using examples from dialect research as well as museum and heritage studies, it points out a conscious usage of culture in everyday life and states the need for a more elaborate understanding of the concepts of culture and the way they are perceived, negotiated and used by different actors.

Keywords: heritage, circulation of knowledge, propertization of culture, everyday experience of heritage.
Na podlagi izhodišca, da moramo danes zvezo "delatil ustvarjati kulturo « razumeti hkrati kot"delovati v kulturi" in "delovati s kulturo", prispevek obravnava nove perspektive na kompleksnem področju kulturne dedišcine. $Z$ zgledi iz raziskav narečij, muzejev in dedišcinski študij opozarja na zavestno rabo kulture v vsakdanjem življenju in ugotavlja potrebo po bolj iztanjšanem razumevanju konceptov kulture in načina, kako kulturo dojemajo, obravnavajo in uporabljajo različni akterji.

Ključne besede: dedišcina, kroženje znanja, prilaščanje kulture, vsakdanje doživljanje dediščine.

"Contemporary appropriations of cultural heritage": The title of this section of the conference "Tradition and Cultural Heritage" suggests that heritage is always a contemporary phenomenon and that it always contains a notion of usage, too. Attending the lectures and discussions confirmed my presumptions of heritage as the new common (sense) form of culture.

Heritage as a form of culture: this is the impression that one gets in dealing with everyday narrations and practices, especially in European Ethnology. At the same time, the culture examined serves as an analytical tool of academic research and as an instrument of self-portrayal as well as a portrayal by others in everyday life. My thesis is that, today, habitual culture and "meta-cultural" heritage (Kirshenblatt-Gimblett 2004) are intertwined and circularly interrelated in a way that they can no longer be separated into two different modes. The legitimacy of the "use of culture" is beyond question. However, cultural research continues to be challenged in new ways - especially when the adopted cultural heritage becomes a means of political and economical action (Tschofen 2007).

Based on the premise that, today, "doing culture" has to be understood as both "acting in culture" and "acting with culture", this paper uses the experiences and results from current research projects as a basis for discussion. The examples are taken from the fields of ethnolinguistics, respectively dialect research, culinary studies, and, finally, museum and heritage studies. They combine various differing questions and, thus, inquire about the benefit of alternative and complementary categories (e.g. practice, knowledge, emotion) and the possibilities of a sophisticated understanding of the concepts of culture, how those are experienced, dealt with and used by various actors in the sphere of everyday life. In doing so, they could also lead back to an integrated cultural analysis. 


\section{DESCRIBING SELF-DESCRIPTIONS: \\ ETHNOGRAPHICAL INSPECTIONS TO SELF-PORTRAYALS THROUGH HERITAGE}

Let me outline the topic discussed here with the help of an example. It is taken from a field which has become a personal passion of mine during the last years.

The story is an example for our discipline's fine line between application and fieldwork. Nearly always, our work with institutions - with the media, with museums, public and private organizations - is a field of experiences and expertise in regards of cultural action. But first and foremost it is an example for how our being involved in this field provides knowledge to and affects the field - often to an extent of "cultural brokerage" (Kirshenblatt-Gimblett 2000).

In brief: As head of the scientific board I support an association that focuses on studying the history and culture of skiing in the Arlberg region in my home country of Austria. It is an interesting activity in which I not only have had the chance to learn a lot about the history of tourism, but in the cooperation with the regional actors I can also learn quite a lot about the importance of cultural knowledge today. The region labels itself as the "Wiege des alpinen Skilaufs" (the cradle of Alpine skiing) and is committed to turn this image into a resource - in fact, a resource in a double sense: for the strengthening of the "Arlberg" brand as well as for the social and political mobilization of the history of skiing as a success story of the region serving purposes of identity building and regional development (Hemme et al., eds. 2007).

Those interviewed (hotel owners, skiing instructors etc.) by the scientific staff of the project continuously pointed out the 'specific way' of the Arlberg region into what one could call the touristic modernity. The distinctions are less to be found on the objective level but in the subjective interpretations of collective experiences. Indeed it is - if you like - a "tourism of the natives", which has established its most modern forms by a grass roots initiative and has found its own ways of expression in doing so. To a very large extent, this development happened without foreign investors as in other alpine regions, where those investors have built the bases for contemporary winter sport and tourism industries.

The strong mark of skiing culture on the region has developed a certain awareness that allows for a high rate of reflection. Skiing and winter tourism - the complex of the so called "wonder in white" of the Arlberg - are conceived as sources of a regional identity (which is also sometimes seen skeptical) and as cultural heritage which one wants to know more about and which is understood as a major resource for future development. With the progress of the project's work which is funded by the EU LEADER program, it was only a question of time, until the question had to been raised, if there was a realistic chance for claiming the status of UNESCO intangible heritage for the "Arlberg school of alpine skiing" and the connected touristic surrounding: "What is possible for French cuisine and Viennese hospitality must be possible for us too!" 
The term Skikultur (skiing culture) was brought into discussion by the scholars in the board as an open concept for our work. It was meant to cover the extensive cultural and social dynamics which had been initiated by ski sports and tourism. The use of a cultural term granted for a higher legitimacy of the research proposal. The jump from "skiing culture" as an analytical tool to a reclaimed normative category was a short one - just 'wedeling' once, to put it metaphorically.

But there is another heritage story within: If you ask the local actors about their experiences with tourism and winter sport, you will come across the so called Walser tradition of the region again and again - and this is quite irritating, at least initially. The myth of the "free Walser", medieval immigrants from the Swiss Valais: a myth which has been fostered by historians, by ethnology and regional studies since the $19^{\text {th }}$ century, has engraved itself into the place in a way that it serves to justify today's social practice and highlight it with historical meaning.

The antagonism could not be stronger. Here: one of the most developed tourism industries in the Alps, there: the constant reference to the settlers who immigrated 700 years ago from the Valais. With the decline of the historical privileges of the Walser in the time of the modern nation-state the settlers' distinction has become available for a secondary mobilization to a certain extend: as a mythomoteur (Smith 1986) for the interpretation of their situation as that of a kind of Alpine diaspora (and with it a motor for a rather inexplicable distinction from the surrounding areas).

Today, Lech and Zürs, the main Walser villages in the Arlberg region, are particularly proud of their self-imposed restriction of touristic growth. And - of course - the Walser tradition accounts for this: One states that the skiing resort is used like a Allmende (the traditional common land, a public good), another one insists on old rights and old chartered liberties - and last not least, one argues for the traditional commons to restrict foreign investors' access to the region's natural resources.

Where does such knowledge come from? If you look into the origins of these concepts and ideas, you will inevitably discover an intensive transfer of knowledge between local elites and academic experts: a circulation of knowledge which dates back to the early $19^{\text {th }}$ century and helped to communicate the idea of a unique status of the Walser traditions into the local communities. Public representations and rituals contributed vastly to this process. Today, the myth of the charter has engraved itself in a sustainable way to this extent that it is taken for material reality a long time ago.

With my example I will try to point out three aspects of our topic:

The first aspect can be understood as a circulation of knowledge. It is an aspect which is mainly important for the self-portrayals of the Walser but also touches the interests in skiing history. Thereby, knowledge about ethnic and historical distinctions of the area can be regarded as the starting point of contemporary acting and arguing.

The second aspect deals with the paradigm of cultural heritage, its different formats and effects. This aspect also relates to the economization - or better: propertization- of culture. 
Third, the example shows that the practices of knowledge and processes of cultural transformation do not only reach into the dimension of imaginations or symbolizations, but furthermore have become an unavoidable frame of action for the people themselves. This refers, for example, to a very modern form of "traditional" hospitality or to the integration of the touristic and sportive past into the reflections and updates of this "heritage". Both aspects can be found in the skiing area and in the village at more and more sites.

- Circulation of knowledge and knowledge about culture

- Heritage and propertization

- Materiality and emotion

These three dimensions serve as the keywords for the rest of the paper. The following paragraphs provide insight into current projects at our department in Tübingen in the field of cultural heritage (in a broader sense). The examples show that traditional custom and usage of culture no longer pose an antagonism and, with it, cannot be regarded as opposite dimensions of cultural practice. The pattern of thought of a "technical world as the natural environment" was already introduced by Hermann Bausinger in the early 1960s (Bausinger 1990).

\section{CIRCULATIONS OF KNOWLEDGE AND KNOWLEDGE ABOUT CULTURE: SOME EXAMPLES FROM ETHNOLINGUISTICS}

About two years ago, we have launched a project called Sprachalltag (everyday language) at our department. The approach of the project is to carefully renew an important tradition in this field. In addition to that, it is also a new approach to a field of study which does not play a significant role in modern German European Ethnology any more.

After several years of being absent in this field, the project at the same time sheds new light on our important dialectological archives - both important due to reasons of the history of science in our fields and for a comparative approach to the dynamics of an everyday linguistic culture. This material is needed if you want to find out something about the development of social and spatial ranges of dialects (and regional languages).

On the other hand, the project enables ethnographic work in the field of 'acting with culture' in contemporary daily life. For this reason, it not only contributes to cover an old field of research interest, but also to the solution of more general questions of European Ethnology.

The phenomena mentioned above had been outlined by European Ethnology in the past again and again. Under the impression of a critique of "folklorism" (Moser 1962), they were counted as a so called Rücklauf(return run) for a long time: a formerly legitimate but often obsolete knowledge, a form of knowledge which flows back into the field and engraves itself into the self-interpretation of popular practice. This explanation was 
found to be insufficient from very early on (Bausinger 1966). Therefore, a problem had been pointed out which accompanies Folklore and Ethnology since their early beginnings: the problem lays in the specific epistemic condition of a discipline which (re)claimed the authenticity of its objects (Bendix 1997) and, at the same time, wanted to have an impact on daily practice. This problematic condition is very crucial for the status of disciplinary knowledge and it outlines the relationship of the discipline to different audiences - which have become an important aspect of discourse in recent times (Bendix and Welz, eds. 2002).

The developments of the concept of culture had never been conceivable during the years of disciplinary modernization in the 1960s and 1970s. Regardless of the crisis of this concept in culture research (Lindner 2002), culture has become the most influential category of self-interpretation in late modernity. Sadly, this even concerns the fact that, in summer of 2011, the Oslo assassin in his crude ideas made central use of two terms which are composites of culture: multiculturalism and cultural Marxism.

Changes in the orders of our knowledge-based societies and a general permeability between the formerly separated fields of popular culture, media culture, and scientific culture contributed immensely to this historical upswing (Lindner 1995). Against this background, such relations can be understood in a new way even in their historical dimension. Instead of a unidirectional popularization, the important aspect is the circular relatedness of different dimensions of an interdependent and interrelated structure (Tschofen 2011).

Contemporary research frequently refers to this specific situation which is based on the epistemic tradition of Ethnology. In their fieldwork, the members of the projects' staff, $\mathrm{PhD}$ students, inquire about the status and function of regional varieties of dialects. In doing so, they encounter local dialect-experts everywhere. The field is full of experts who have no problem to argue with a concept of culture in order to explain the specifics of their local dialects (quite frequently, they are well prepared for the interviews and well read in the literature on these topics). By "speaking about language", the actors encountered by our PhD-students illustrate the availability of the use of linguistic knowledge as a part of a spatial but also social positioning in everyday life (Klausmann and Tschofen 2012). This is not only a question of subjective linguistic spaces, which have been described in the last years by recent linguistics, for example. It is furthermore a question of attention for the deliberate adoption of such knowledge. As our first results show, people use their dialect knowledge mainly for negotiating the symbolic range of varieties: where does 'our language' end and another one begin? And of which value are they?

In her dissertation Nina K. Leonhardt, one of our PhD students inquires about how these borders between dialects are perceived and conveyed in local communities. During her research she came across a rich repertoire of terms and argumentations highlighting the comparison of own experiences with conveyed historical or social differences. The linguistic memory is approved and renewed by speaking about language, too. With reference to established terminologies and characteristics it enables the negotiation of linguistic belonging and of the meaning of varieties (Bürkle and Leonhardt, forthcoming). 
Ethnography - seen as a way of understanding culture which was used to deal with the authentic - is permanently challenged with new questions by this kind of circulating knowledge. Ethnography and cultural research have to become aware that the practices of self-interpretation of the researched are not an indication of illegitimate academic knowledge. For our discipline, seeking to understand the everyday dimension and use of culture under contemporary conditions, it is very important to regard such topics and questions as a legitimate object. However, it appears that the role of scholarship itself is permanently scrutinized. The keyword "reflexivity" sometimes seems to serve as protective shield superseding deeper insights by using it.

In the next part, I will deal with a new topic, or rather a new perspective to the topic.

\section{HERITAGE AND PROPERTIZATION: \\ SOME EXAMPLES FROM CULINARY STUDIES (GI - GEOGRAPHICAL INDICATIONS)}

Newspapers quite frequently run stories about regional (and national) cheese wars within the European Union. Currently, Bavarians fear that their specialty called Obazda (a typical cheese spread) is produced in neighboring regions. Poland and Slovakia already had their corresponding conflicts around Oscypek/Ostiepok when they applied for membership to the EU several years ago (Tschofen 2008). Again and again, cases regarding the European system of Geographical Indications are taken to court. This system of Geographical Indications is the focus of our interdisciplinary project together with colleagues from agricultural economics. It is associated with the framework of the Göttingen working-group on "cultural property" (Bendix et al., eds. 2010).

In this project we analyze regulations and effects of the EU system for the protection and valorization of "Geographical indications and traditional specialities" $(1992,2006)$ and their three schemes (PDO, PGI and TSG). Thereby, we focus on both structures of governance and everyday practice in a cultural property regime, which, at the same time, connects consumers and producers. Starting from a dynamic understanding of geographical indications (Bicskei 2012), we are working on an integrated ethnographical and economical analysis. In doing so, we focus exemplarily on products and regions in Germany and Italy and compare those with a high visibility to those with a lower one. We try to reconstruct the contexts of reasoning and legitimization within the framework of processes of application. Therefore agencies and limitations are as well investigated as economic and cultural effects. On the level of acting regional stakeholders, we mainly focus on the mediation of local needs and European as well as national governance structures of the European agricultural market. In a next step, we try to develop approaches to the consumer's concepts of geographical indications and regional specialities. On a level of application of our results, our goal is to provide recommendations for a better practice - that means mainly for a more transparent shaping and use of the system. 
On the one hand, this field exemplifies the problem of territorial (regional) dimensions of cultural property. On the other hand, with its focus on the EU's agricultural and cultural policy, it is concerned with a post-national regime with a far-reaching influence on everyday life (Tschofen 2008). Analyzing the processes of geographical indication it also encounters a central problem of intellectual property - a problematic field indicated by the use of a cultural term (culinary heritage) in this rather economical and political field. Beyond that, the project leans towards other systems of managing and transforming cultural heritage.

What happens in this field? Although it is intended as a system for the protection of yet existing regional and traditional specialties (a system for safeguarding both producers and consumer interests), it proves to be a generator of heritage production and of branding processes arguing with regional and traditional distinctions. Much less the conservation - as intended by the EU - but rather the constitution of property-like goods is the central effect of the system. So called "followers" try to benefit from the chances offered with the argument of "culture" to compete with the strong brands on the European agricultural market.

The starting point of our research is to inquire about the functions of the instruments of the EU agricultural policy and their use in different national and regional settings (Germany/Italy - local range/super-regional range). We focus especially on so called "cultural specification", a document which is crucial for the application and monitoring processes within the system - specification is the key argument in which regional and historical distinctions have to be documented and explained. Thereby, knowledge about culture becomes an initial point of argumentation including emotional values and offers possibilities of identification. To reconstruct such processes of transformation, the study of Geographical Indications has to expand from self-interpretation of the consortia and regions to the question of the effects on experiences and sensory inscriptions. The influence of embodied knowledge plays a crucial role, because plausibility and visibility of the products are based on elementary experiences of tasting and smelling. These experiences are the basis of an inner map of European consumers - distinguishing regions and products in terms of culinary culture.

\section{MATERIALITY AND EMOTION: SOME EXAMPLES FROM MUSEUM AND HERITAGE STUDIES}

Understanding that "doing culture" refers to both "acting in culture" and "acting with culture", especially in regard to the museum as a central field of study and practice in our discipline goes without doubt.

Since 2010, we are studying what happens in the museum in a state-funded research project with partner institutions from different disciplines and the museum itself. In doing so, we do not focus on the construction and representation of cultural orders alone, but also 
focus on the relatedness of the different actors in the museum field. What happens if the authentic atmospheres of everyday or work-life of famous men of letters are reconstructed? What if - like in the house of Ernst Jünger - steel helmets and rolls of adhesive tape change not only their place but also their status within the epistemic constellation? (Hartmann, forthcoming) Or what happens when tourists go on trekking tours in the traces of the so called "man in the ice" and encounter heritage sites in the landscape that had been prepared for TV documentaries? What happens if, in doing so, they enter arrangements in which embodied experiences and media framed interpretations interact? In other words: What do people do with things and what do things do with people, and vice versa? Following a translational concept of culture, the question about the construction and experience of evidence is crucial for us. Consequently, this approach requires to understand the museum and heritage objects in their relation to popular experience, and it helps to discover the informal energy of traditional goods. Alois Riegl, a turn-of-the-century Austrian art historian, has called this the Stimmungswert (which could be translated as "value of atmosphere/ ambiance") of the past (Riegl 1903). That people have their own ideas about and concepts of universal orders and try to detect parts of their own life in historical monuments is, thus, not a new thought. You can find quite similar ideas in later theories which deal with the special moment of combining past and present in affective encounters with history.

Those concepts need to be mentioned because they are of a high value for contemporary museum and heritage studies. The following questions are urgent: Why do heritage sites and museum objects appear to have such high evidence to present societies? What is it that makes those objects and sites appear emanating? Those aspects connect to lived experiences and they show that significance is not universal, and it can be distinguished on a historical and social (cultural) scale. The dimension of experience is therefore crucial for the way people think about culture, for the way they make use of culture and how they act with culture. Consequently, the atmosphere of a traditional ritual or a museum space is not a given fact, but a result of the interrelation between the material bases and the human counterpart. Such concepts have been developed by Gernot Böhme ("Atmospheres"; Böhme 1995) for cultural theory and by Sharon MacDonald - in the sense of affordances written in monuments - for heritage and museum studies (e.g. MacDonald 2006). These concepts can be very productive for ethnographical approaches to the heritage field. The question they raise is about experiencing heritage and therefore about the possibility to learn how to be affected by certain places, things or artifacts. When cultural energies and authenticity are regarded in a relativistic way as specific constellations between human and non-human actors this of course has certain (unavoidable) consequences for our empirical methods. This is one of the reasons why we try to pay great attention to the exploration of new methods - such as visual ethnography and others (Weith 2012). If you want to understand different uses of culture, you consequently need new methods which help to discover embodied spatial practices and give visibility to implicit (and non-verbalized) dimensions. I think this is the only possible way to understand recent popular practices 
- practices which are simultaneously drawing from and actualizing cultural memory as they are changing objects and places.

HERITAGE AS A CHALLENGE TO ETHNOGRAPHY AND CULTURAL ANALYSIS:

AN OUTLOOK

Not only do the contexts discussed above have consequences for the perception of the cultural field and for this reason for the relationship to the object of cultural analysis, they also strongly relate to the status of culture in public (Tschofen 2006). In doing so, they have to deal with the self-conception and the aim of humanities such as European Ethnology and Cultural Anthropology (Eggmann 2009; Windmüller et al., eds. 2009). As empirical disciplines we are demanded to develop a greater sensibility for both, the powerful impact of our categories and the reflection of applied practice. A great sensibility for these aspects is necessary because the attraction as well as crux of Ethnology are interrelated with the fact that culture is not just an analytical tool but first and foremost that it is public. To put it with Clifford Geertz, it holds true for cultural heritage as well that "culture is public, because meaning is" (Geertz 1973: 12).

With my examples from different research projects, I tried to demonstrate, that, in recent times, these aspects of "doing culture" are particularly evident. Like in the case of cultural heritage, culture becomes a source of value-added practices: through processes of transforming knowledge and through its application to processes of social engineering. Consequently, the theoretical and the performative dimension of culture are interconnected by circular references.

In a paper discussing the heritage boom, Barbara Kirshenblatt-Gimblett (2004) coined the term of "metacultural production". Today (and maybe in modernity in general), the "metacultural" is the usual mode of application (Briggs 2002) - I don't need to give further examples. Such examples are plentiful in everyday life, and, not least, they show that a reflexive status of culture is self-evident today. With reference to a long tradition of producing ethnological knowledge in Europe (Häner 2010; Keller-Drescher forthcoming), we are advised not to divide different modes of culture or tradition - such as a habitual and a secondary mode, a natural status and a modern and reflected one.

Therefore, research in these fields makes evident that a reflexive supervision of the research processes themselves is very important. Beyond that, studies on ways and modes of the appropriation of heritage give reason for further discussions on the "role of academic actors in the expanded spaces of producing and procuring knowledge" (Fenske 2011: 121). 


\section{REFERENCES}

Bausinger, Hermann

1966 Zur Kritik der Folklorismuskritik. In: Bausinger, Hermann (ed.), Populus Revisus. Beiträge zur Erforschung der Gegenwart. Tübingen: Tübinger Vereinigung für Volkskunde, 61-75.

1990 (1961) Folk Culture in a World of Technology. Bloomington: Indiana University Press.

Bendix, Regina

1997 In Search of Authenticity: The Formation of Folklore Studies. Madison: University of Wisconsin Press.

Bendix, Regina and Gisela Welz (eds.)

2002 Kulturwissenschaft und Öffentlichkeit. Amerikanische und deutschsprachige Volkskunde im Dialog. Frankfurt am Main: Institut für Kulturanthropologie und Europäische Ethnologie der Johann Wolfgang Goethe-Universität.

Bendix, Regina et al. (eds.)

2010 Die Konstituierung von Cultural Property. Forschungsperspektiven. Göttingen: Universitätsverlag Göttingen (Göttinger Studien zu Cultural Property; 1).

Bicskei, Marianna et al.

2012 Reform Proposals on the Geographical Indications of the European Union for the Protection of Traditional Knowledge. The WIPO Journal 3 (2): 222-236.

Böhme, Gernot

1995 Atmosphäre. Essays zur neuen Ästhetik. Frankfurt am Main: Suhrkamp.

Briggs, Charles

2002 Öffentlichkeit neu denken. Anmerkungen zur metakulturellen Rhetorik. In: Bendix and Welz, eds. 2002, 291-296.

Bühler, Rudolf et al. (eds.)

forthcoming Sprachkultur-Regionalkultur. Neue FelderkulturwissenschaftlicherDialektforschung. Tübingen: Tübinger Vereinigung für Volkskunde (Tübinger kulturwissenschaftliche Gespräche; 7).

Bürkle, Rebekka and Nina K. Leohardt

forthcoming Doing Culture with Dialects - Regional Speech as Cultural Practice. In: Johler, Reinhard et al. (eds.), Out of the Tower: Studies in Culture and Everyday Life. Tübingen: Tübinger Vereinigung für Volkskunde.

Eggmann, Sabine

2009 Öffentliche Wissenschaft. Zur Dreidimensionalität der Volkskunde/Europäischen Ethnologie/ Empirischen Kulturwissenschaft. In: Windmüller et al. (eds.) 2009, 156-161.

Fenske, Michaela

2011 Kulturwissenschaftliches Wissen goes Public. Einblicke in den Aktionsraum von Wissenschaft und Öffentlichkeit am Beispiel volkskundlicher Enzyklopädien. Historische Anthropologie. Kultur - Gesellschaft - Alltag 19 (1): 112-122.

Geertz, Clifford

1973 Thick Description: Toward an Interpretive Theory of Culture. In: Geertz, Clifford, The Interpretation of Cultures. New York: Basic Books, 3-30.

Häner, Flavio

2010 Und was macht man später damit? Transformationsprozesse volkskundlichen Wissens zum ökonomischen Gut. Saarbrücken: Vdm. Verlag Dr. Müller (Basel Univ. Liz.).

Hartmann, Felicitas

forthcoming Miscellanea or works? Collecting and exhibiting as practices constituting an author's oeuvrethe example of the estate of Ernst Jünger. In: Johler, Reinhard et al. (eds), Out of the Tower: Studies in Culture and Everyday Life. Tübingen: Tübinger Vereinigung für Volkskunde. 
Hemme, Dorothee et al. (eds.)

2007 Prädikat „Heritage“. Wertschöpfungen auskulturellen Ressourcen. Münster: LIT-Verlag(Studien zur Kulturanthropologie/Europäische Ethnologie; 1).

Keller-Drescher, Lioba

forthcoming Landesbeschreibung als Wissensformat. Ansätze zu einer vergleichenden Analyse. In: Johler, Reinhard and Josef Wolf (eds.), Beschreiben und Vermessen. Raumwissen in der östlichen Habsburgermonarchie im 18. und 19. Jabrhundert. Berlin: Frank \& Timme.

Kirshenblatt-Gimblett, Barbara

2000 Folklorists in Public: Reflections on Cultural Brokerage in the United States and in Germany. Journal of Foklore Research 37 (1): 1-22.

2004 Intangible Heritage as Metacultural Production. Museum International 56 (1-2): 52-65.

Klausmann, Hubert and Bernhard Tschofen

forthcoming Dialekt und Alltagssprache. Kultur-und sprachwissenschaftliche Fragen zur sprachlichen Gegenwart am Beispiel Nord-Baden-Württemberg. In: [tba].

Lindner, Rolf

1995 Kulturtransfer. Zum Verhältnis von Alltags-, Medien- und Wissenschaftskultur. In: Kaschuba, Wolfgang (ed.), Kulturen - Identitäten - Diskurse. Perspektiven Europäischer Ethnologie. Berlin: Akademie-Verlag, 31-44.

2002 Konjunktur und Krise des Kulturkonzepts. In: Musner, Lutz and Gotthart Wunberg (eds.), Kulturwissenschaften. Forschung - Praxis - Positionen. Wien: WUV, 69-87.

MacDonald, Sharon

2006 Words in Stone? Agency and Identity in a Nazi Landscape. Journal of Material Culture 11 (1-2): $105-126$.

Moser, Hans

1962 Vom Folklorismus in unserer Zeit. Zeitschrift für Volkskunde 58: 177-209.

Riegl, Alois

1903 Der Moderne Denkmalkultus. Sein Wesen und seine Entstehung. Wien and Leipzig: Braumüller.

Smith, Anthony D.

1986 The Ethnic Origins of Nation. Oxford: Blackwell Publishing.

Tschofen, Bernhard

2006 Vom Alltag. Schicksale des Selbstverständlichen in der Europäischen Ethnologie. In: Bockhorn, Olaf et al. (eds.), Alltagskulturen. Forschungen und Dokumentationen zu österreichischen Alltagen. Wien: Selbstverlag des Vereins für Volkskunde, 91-102.

2007 Antreten, ablehnen, verwalten? Was der Heritage-Boom den Kulturwissenschaften aufträgt? In: Hemme, Dorothee et al. (eds.) 2007, 19-32.

2008 On the Taste of the Regions: Culinary Praxis, European Politics and Spatial Culture - A Research Outline. Anthropological Journal of European Cultures 17 (1): $24-53$.

2011 Volks-Kunde? Wissenszirkulationen zwischen Kulturforschung und Selbstauslegung. Nach Feierabend. Zürcher Jahrbuch für Wissensgeschichte 7: 37-52.

Weith, Carmen

2012 Alb-Glück. Zur Kulturtechnik der Naturerfahrung. Tübingen: PhD Dissertation.

Windmüller, Sonja et al. (eds.)

2009 Kultur - Forschung. Zum Profil einer volkskundlichen Kulturwissenschaft. Berlin/Münster: LIT-Verlag. 


\section{DEDIŠČINA - SODOBNE RABE KULTURE ČEZ MEJE VSAKDNJIKA. IZZIV ZA ETNOGRAFIJO IN KULTURNO ANALIZO}

Mikavnost kakor tudi jedro evropske etnologije temeljita na dejstvu, da se ta veda ukvarjas splošnimi dobrinami. Njena osrednja kategorija - kultura - je analitično orodje akademskega raziskovanja in sredstvo samoupodabljanjalsamopredstavitev in upodabljanjalpredstavitev drugih v vsakdanjem življenju. Vendar se je evropska etnologija morala že zelo zgodaj naučiti, da tega dejstva ne gre razumeti zgolj kot nasprotje: kar se zdi kot nasprotje med objektivnim in subjektivnim načinom kulture kot ločenih vrst kulture, je v resnici tesno povezano. Krožne oblike sklicevanj potrjujejo, da takšne dihotomije več ne zdržijo. To je eden izmed razlogov za upadlo zaupanje v analitično moč "kulture". Pogosto je laže opisati in dekonstruirati kulturno dediščino z razpoložjivimi koncepti naše vede, kakor jo priznati kot nov razdelan način kulture, predstavljen $v$ tem sestavku.

Kot empirična veda, osredinjena na vsakdanje življenje, popularno in številne načine upodabljanja sveta, se kljub opisanemu položaju ne more ogniti kulturi kot konceptu. Poleg tega je treba razviti večjo občutljivost za različne načine "ustvarjanja kulture", ki se posebej kažejo v zvezi s kulturno dedišcino; za prakse, ki so hkrati podvržene hitrim spremembam in pomagajo ustvarjati kontinuiteto, in za interpretacije, ki so hkrati samoumevne in izrazito kontradiktorne. To zahteva, da veliko pozornost namenimo načinu, kako se akademski koncepti nanašajo na ureditve in prakse vsakdanjika.

Na podlagi izhodišča, da moramo danes zvezo "delati/ustvarjati kulturo" razumeti hkrati kot "delovati v kulturi" in "delovati s kulturo", so v prispevku za izhodišce razprave uporabljene izkušnje in spoznanja tekočih raziskovalnih projektov. Zgledi so iz raziskav narečij v polju etnolingvistike, raziskav kulinarike in naposled studija muzejev in dediščine. V njih se prepletajo različna vprašanja in s tem premisleki o koristih alternativnih in komplementarnih kategorij (npr. prakse, znanje in čustva) ter možnostih iztanjšanega razumevanja konceptov kulture, kakor jih doživljajo, obravnavajo in uporabljajo različni akterji v vsakdanjem življenju. S tem bi se bilo mogoče vrniti $k$ celostni kulturni analizi.

Prof. Dr. Bernhard Tschofen, Ludwig-Uhland-Institut für Empirische Kulturwissenschaft, Eberhard Karls Universität Tübingen, Schloss (Burgsteige 11), D-72070 Tübingen, Germany, bernhard.tschofen@uni-tuebingen.de 